\title{
Evaluate the Performance of Pigeon Pea (Cajanus cajan) as Influenced by Varieties and Plant Geometry in Rain fed Condition
}

\author{
Aditya Kumar Singh* \\ Deendayal Research Institute, Tulsi Krishi Vigyan Kendra, Ganiwan, \\ Chitrakoot (UP) 210206, India \\ *Corresponding author
}

\section{Keywords}

Pigeon pea, Plant geometry, Rain fed condition, Varieties,

Yield and

economics

\section{Article Info}

Accepted:

17 June 2018

Available Online:

10 July 2018

\section{A B S T R A C T}

A field experiment was conducted during kharif 2015 at Krishi Vigyan Kendra, Ganiwan, Chitrakoot district of Bundelkhand region of Uttar Pradesh on silty loam soil to assess the effect of varieties and plant geometries on rain fed Pigeon pea crop. Treatments comprised of 3 levels each of variety (UPAS 120, Bahar 777, ICPL 88039) and planting geometries (Uniform $50 \mathrm{~cm}$ routs, paired row $40 / 60 \mathrm{~cm}$, uniform 60 rows). Results revealed that varieties did not differed significantly from each other in growth, yield attributes, yield and economic parameters only with one exception of number of pods/plant which was found maximum of 68.03 pods / plant in UPAS- 120 . However, numerically UPAS-120 produced highest of $981.00 \mathrm{~kg} / \mathrm{ha}$ seed yield and earned maximum net return of Rs. 25494/ha with $2.34 \mathrm{~B}$ : C ratio, other two varieties Bahar 777 and ICPL 88039 produced 923.50 and $928.46 \mathrm{~kg} / \mathrm{ha}$ seed yield and earned Rs. 23279 and 23155 /ha not return with 2.22 and 2.20 B:C ratio, respectively. Among plant geometries, uniform $60 \mathrm{~cm}$ rows planting attained highest values of growth and yield attributes, thus produced significantly highest of $1164.30 \mathrm{~kg} / \mathrm{ha}$ seed yield and earned maximum of Rs. 33336/ha net return with $2.74 \mathrm{~B}: \mathrm{C}$ ratio. Other plant geometries of uniform $50 \mathrm{~cm}$ rows and paired rows $40 / 60 \mathrm{~cm}$ produced 805.92 and $862.73 \mathrm{~kg} / \mathrm{ha}$ seed yield and earned Rs. 18182 and 20410/ha net return with 1.95 and $2.07 \mathrm{~B}$ : C ratio, respectively. Thus, uniform $60 \mathrm{~cm}$ rows planting produced 44.5 and 35.0 of higher seed yield and earned 83.3 and $63.3 \%$ higher net return than uniform 50 $\mathrm{cm}$ rows and paired row $40 / 60 \mathrm{~cm}$ planting, respectively.

\section{Introduction}

Pigeon pea (Cajanus cajan) is an important pulse crop of rain fed agriculture because of its ability to produce economic yield under limited moisture conditions. It occupies the second position among pulses in India only after chick pea. The release of new short duration harvest index through better utilization of monsoon rains during both vegetative and reproductive phases. These genotypes after great promise for introduction of Pigeon pea in new as well as in existing cropping systems. Maintenance of optimum plant population per unit area in proper geometry is an important test in rain fed crops 
like Pigeon pea to exploit the yield potential of any genotype. Short duration Pigeon pea varieties are in general short statured with different compactness. Thus, those may require different plant geometry for proper development of individual plant on which yield depends. Though such short duration Pigeon pea genotypes have higher yield potential, their achievable yields are comparatively poor. To achieve their yield potential in a given environment, proper selection of most suitable variety and maintenance of optimum plant stand per unit area in proper geometry is necessary. With this view, the present study was carried out in Chitrakoot district of Uttar Pradesh.

\section{Materials and Methods}

A field experiment was carried out during kharif, 2015 on rain fed Pigeon pea at Tulsi Krishi Vigyan Kendra, Ganiwan, Chitrakoot (U P). The soil of experimental field was silty loam in texture, slightly alkaline in reaction $(7.6 \mathrm{pH})$ and having $0.29 \%$ organic carbon, $10.48 \mathrm{~kg} / \mathrm{ha}$ available $\mathrm{P}_{2} \mathrm{O}_{5}$ and $206 \mathrm{~kg} / \mathrm{ha}$ available $\mathrm{K}_{2} \mathrm{O}$. The treatments comprised 9 combinations of 3 varieties viz. UPAS-120, Bahar-777, ICPL-88039 and 3 plant geometry viz. Uniform rows at $50 \mathrm{~cm}$ spacing, paired rows at $40 / 60 \mathrm{~cm}$ spacing and uniform rows at $60 \mathrm{~cm}$ spacing plant spacing within row was maintained uniform $10 \mathrm{~cm}$ in all treatment plots by thinning extra plants at the crop stage of 20 days after sowing.

The experiment was laid out in split plot design with main plots to varieties and sub plots to plant geometries replicated thrice sowing of pigeon pea varieties seed was done behind country plough in furrows as per treatment @ $20 \mathrm{~kg} / \mathrm{ha}$ in all plots on $06^{\text {th }}$ July, 2015. An uniform dose of $20 \mathrm{~kg} \mathrm{~N}+50 \mathrm{Kg}$ $\mathrm{P}_{2} \mathrm{O}_{5}+20 \mathrm{~kg} \mathrm{~K} 2 \mathrm{O} / \mathrm{ha}$ was applied through Diammonium phosphate and muriate of potash fertilizers, respectively in whole experimental area as deep furrows placement with the help of a funnel attached with country plough used for seed sowing. Other than treatments, the experimental crop was raised with recommended package of practices. The crop was harvested at about $90 \%$ pods maturity. In its life cycle, experimental crop received a total of $853.65 \mathrm{~mm}$ well distributed rainfall. The observations were recorded on final plant stand at harvest, growth characters, yield attributes and crop yields at final stage of crop harvest, while root studies were done at the crop stage of 90 days after sowing. Economics of pigeon pea cultivation was also worked out under different treatment considering the prevailing market prices of different inputs and yield products. All data were analysed statistically in split-plot design as prescribed by Panse and Sukhatme (1957).

\section{Results and Discussion}

\section{Growth characters}

None of the growth characters studies affected significantly by different Pigeon pea varieties (Table 1). All varieties remained at par with each other. Among plant geometries, paired row $40 / 60 \mathrm{~cm}$ planting being at par with uniform $50 \mathrm{~cm}$ rows planting maintained significantly more plant stand per unit area than uniform $60 \mathrm{~cm}$ rows planting. The reduction in plant stand under wider row spacing of $60 \mathrm{~cm}$ might be attributed to lesser number of rows per unit area because plant spacing within row was maintained similar in all plant geometries. Number of branches/plant was recorded significantly maximum under uniform $60 \mathrm{~cm}$ rows planting. It might be the effect of spacing between crop rows where wider space provided favourable environment to crop plants for producing branches profusely and vice-versa. It is in agreement to the findings of Kumawat et al. (2013). 
Root length was measured significantly deeper under paired row planting whereas root spread was found significantly more under uniform $60 \mathrm{~cm}$ rows planting. It might be attributed to underground root competition for their development where horizontal lesser space in paired planting forced the roots to penetrate deeper in the soil while in wider rows planting lateral spread of roots was more because of sufficient available space. Number of nodules/plant and dry weight of root nodules/plant were recorded significantly highest under uniform $60 \mathrm{~cm}$ rows planting and lowest under uniform $50 \mathrm{~cm}$ rows planting which might be attributed to more root spread under wider rows planting. These results are in accordance to the findings of Ahlawat and Saraf (1982).

\section{Days to phonological stages}

These were influenced significantly by both treatment factors of varieties and plant geometries (Table 1).

Among varieties, UPAS-120 took significantly minimum number of days to flowering, padding and maturity while maximum numbers of days were taken by ICPL-88039 for all stages by the margin of about 10 days. It might be due to genetic makeup of different genotypes which depends on utilization of growing degree days by a variety denotes its longer period to phonological stages and vice-versa.

These results support the findings of Mishra and Chand (2009). In case of plant geometries, uniform $60 \mathrm{~cm}$ rows planting took maximum number of days while minimum numbers of days were recorded under paired rows planting for flowering, padding and maturity. It might be attributed to vegetative growth of crop plants which was more under uniform $60 \mathrm{~cm}$ rows planting, thus reproductive phase delayed.

\section{Yield attributes and yield}

Different Pigeon pea varieties under test could not differ significantly from each other in all yields attributes (Table 1) and yield (Table 2) only with one exception of number of pods/plant which was recorded significantly more in variety UPAS-120 than other two varieties (Table 1). However, variety UPAS120 produced considerably higher seed yield/ha (5.7 and 6.2\%) than other two varieties which might be attributed to number of pods/plant as reflected in seed weight/plant also. Better performance of variety UPAS-120 in this regard has also been reported by Tripathi and Chauhan (1990). The effect of plant geometries was found significant on number of pods/plant, seed weight/plant, harvest index (Table 1), seed yield and stick + Stover yield/ha (Table 2). All these characters of Pigeon pea were significantly maximized under uniform $60 \mathrm{~cm}$ rows planting. It was followed by paired row planting while uniform $50 \mathrm{~cm}$ rows planting recorded lowest values of above mentioned yield attributes and yields. The plant geometry of uniform $60 \mathrm{~cm}$ rows produced significantly highest of 1164 $\mathrm{kg} / \mathrm{ha}$ seed yield which was found $358 \mathrm{~kg}$ and $302 \mathrm{~kg} / \mathrm{ha}$ or 44.5 and 35.0 per cent higher than the seed yields obtained under uniform $50 \mathrm{~cm}$ rows and paired row planting geometries, respectively. Such higher seed yield might be attributed to number of pods/plant, seed weight/ plant and harvest index. Stick + Stover yield also produced almost in similar manner to seed yield under different plant geometries. These results are in close conformity to those of Kumar et al. (2003) and Kumawat et al., (2013).

\section{Economics}

None of the economic parameters was influenced significantly by Pigeon pea varieties (Table 2). 
Table.1 Effect of varieties and plant geometry on growth characters and yield attributes of pigeon pea

\begin{tabular}{|c|c|c|c|c|c|c|c|c|c|c|c|c|c|c|}
\hline Treatments & \multicolumn{6}{|c|}{ Growth Characters } & \multicolumn{3}{|c|}{$\begin{array}{c}\text { No. of days to } \\
\text { Phonological stages }\end{array}$} & \multicolumn{5}{|c|}{ Yield attributes } \\
\hline \multicolumn{15}{|l|}{ Varieties } \\
\hline UPAS-120 & 16.78 & 20.85 & 19.19 & 16.45 & 0.636 & 24.79 & 90.67 & 119.67 & 140.67 & 68.03 & 3.34 & 8.72 & 9.96 & 21.06 \\
\hline Bahar-777 & 17.56 & 19.36 & 18.31 & 14.96 & 0.603 & 23.88 & 94.67 & 123.67 & 150.00 & 58.36 & 3.26 & 8.73 & 9.45 & 20.14 \\
\hline ICPL-88039 & 17.00 & 20.35 & 18.97 & 14.70 & 0.590 & 23.68 & 99.67 & 129.67 & 150.00 & 59.17 & 3.21 & 8.69 & 9.62 & 20.40 \\
\hline S.Ed. \pm & 0.95 & 0.62 & 0.59 & 0.60 & 0.030 & 0.77 & 0.74 & 0.75 & 1.12 & 1.43 & 0.13 & 0.18 & 0.35 & 0.40 \\
\hline C.D. $(P=0.05)$ & NS & NS & NS & NS & NS & NS & 2.03 & 2.06 & 3.08 & 3.95 & NS & NS & NS & NS \\
\hline \multicolumn{15}{|l|}{ Plant geometry } \\
\hline Uniform $50 \mathrm{~cm}$ rows & 17.55 & 20.07 & 18.72 & 13.33 & 0.542 & 21.13 & 94.33 & 123.67 & 144.33 & 52.35 & 3.33 & 8.76 & 8.16 & 19.34 \\
\hline Paired rows $40 / 60 \mathrm{~cm}$ & 18.22 & 21.39 & 17.91 & 15.23 & 0.601 & 23.75 & 91.67 & 121.00 & 141.67 & 57.77 & 3.31 & 8.72 & 8.98 & 20.25 \\
\hline Uniform $60 \mathrm{~cm}$ rows & 15.56 & 19.11 & 19.84 & 17.55 & 0.686 & 27.47 & 99.00 & 28.33 & 149.67 & 75.44 & 3.18 & 8.66 & 11.90 & 22.00 \\
\hline S.Ed. \pm & 0.93 & 0.72 & 0.60 & 0.65 & 0.030 & 0.75 & 0.70 & 0.82 & 1.30 & 1.57 & 0.12 & 0.20 & 0.47 & 0.34 \\
\hline C.D. $(P=0.05)$ & 2.03 & 1.57 & 1.30 & 1.42 & 0.066 & 1.63 & 1.53 & 1.78 & 2.83 & 3.41 & NS & NS & 1.02 & 0.74 \\
\hline
\end{tabular}

Table.2 Effect of varieties and plant geometry on yield and economics of pigeon pea cultivation

\begin{tabular}{|l|c|c|c|c|c|}
\hline \multicolumn{1}{|c|}{ Treatments } & \multicolumn{3}{c|}{ Yield (kg/ha) } & \multicolumn{3}{c|}{ Economic parameters } \\
\hline Varieties & 981.00 & 3655.51 & 44.587 & 25.494 & $\mathbf{2 . 3 4}$ \\
\hline UPAS-120 & 923.50 & 3639.64 & 42.372 & 23.279 & $\mathbf{2 . 2 2}$ \\
\hline Bahar-777 & 928.46 & 3588.45 & 42.454 & 23.155 & $\mathbf{2 . 2 0}$ \\
\hline ICPL-88039 & 68.11 & 96.08 & 1.131 & 1.133 & $\mathbf{0 . 2 2}$ \\
\hline S.Ed. \pm & $\mathrm{NS}$ & $\mathrm{NS}$ & $\mathrm{NS}$ & $\mathrm{NS}$ & $\mathbf{N S}$ \\
\hline C.D. $(\mathbf{P}=\mathbf{0 . 0 5})$ & & & & & \\
\hline Plant geometry & 805.92 & 3360.02 & 37.344 & 18.182 & $\mathbf{1 . 9 5}$ \\
\hline Uniform 50 cm rows & 862.73 & 3396.11 & 39.571 & 20.410 & $\mathbf{2 . 0 7}$ \\
\hline Paired rows 40/60cm & 1164.30 & 4127.46 & 52.498 & 33.336 & $\mathbf{2 . 7 4}$ \\
\hline Uniform 60 cm rows & 66.06 & 90.68 & 1.117 & 1.135 & $\mathbf{0 . 1 8}$ \\
\hline S.Ed. \pm & $\mathbf{1 4 3 . 9 0}$ & $\mathbf{1 9 7 . 5 3}$ & $\mathbf{2 . 4 3 4}$ & $\mathbf{2 . 4 7 2}$ & $\mathbf{0 . 3 9}$ \\
\hline C.D. $(\mathbf{P = 0 . 0 5 )}$ & & &
\end{tabular}

However, variety UPAS-120 gave numerically highest values of gross income, net return and benefit: Cost ratio. Differences between other two varieties were not found remarkable in any case. Thus, variety UPAS120 recorded 9.52 and 10.10 per cent higher not return than Bahar-777 and ICPL-88039, respectively. It might be attributed to higher seed yield of UPAS-120 compared to other varieties. Tripathi and Chauhan (1990) also reported similar results.

Among plant geometries, uniform $60 \mathrm{~cm}$ row planting recorded significantly highest values of gross income, net return and $\mathrm{B}$ : $\mathrm{C}$ ratio while other two planting geometries remained at par with each other. Thus, the uniform 60 $\mathrm{cm}$ rows planting gave Rs. 15154 and 12927/ha or 40.6 and 32.7 per cent more gross income, earned Rs. 15154 and 12926/ha or 83.3 and 63.3 per cent more net return with 40.5 and 32.4 percent higher $\mathrm{B}: \mathrm{C}$ ratio than uniform $50 \mathrm{~cm}$ rows and paired row plantings, respectively. Superiority of uniform $60 \mathrm{~cm}$ row planting over other plant geometries might be attributed mainly to higher yields of 
seed and stick + Stover. These results concede with the findings of Sharma and Rajput (1996).

The effect of varieties $\times$ plant geometries interaction was not found significant in any observation. Numerically the treatment combination of variety UPAS-120 sown in uniform $60 \mathrm{~cm}$ row spacing proved to be the best for higher production and profitability from rain fed Pigeon pea crop in Chitrakoot district of Bundelkhand region of Uttar Pradesh.

\section{Acknowledgement}

Krishi Vigyan Kendra, Ganiwan is thankful to the Organizing Secretary of Deendayal Research Institute, Chitrakoot for providing facilities for conducting the trails.

\section{References}

Ahlawat, I.P.S. and Saraf, C.S. 1982. Rooting and nodulation pattern in Pigeon pea under different plant densities and phosphate fertilization. Indian Journal of Apronomy 27 (2): 149-55.

Kumar, P., Rana, K.S., Rana, D.S., Anjari, M.A. and Hari Om, 2013. Effect of planting system and phosphorus on productivity, moisture use efficiency and economics of role and intercropped pigeonpea (Cajanus cajan) under rain fed conditions of Northern India. Indian Journal of Agricultural Sciences, 83 (5): 549-54.

Kumawat, N., Singh, R.P., Kumar, R. and Hari Om, 2013. Effect of integrated nutrient management on the performance of role and intercropping Pigeon pea (Cajanus cajan) under rainfed conditions. Indian Journal of Agronomy 58 (3): 309-15.

Mishra, A. and Chand, M. 2009. Effect of weather on phenology and yield of Pigeon pea (Cajanus cajan) in central plain zone of Uttar Pradesh. Current Advances in Agricultural Sciences, 1 (1): 399-04.

Panse, V.G. and Sukhatme, P.V. 1957. Splitplot and Strip-plot designs. Statistical Methods for Agricultural Workers, ICAR, New Delhi Pub. Pp. 199-16.

Sharma, R.K. and Rajput, O.P. 1996. Crop geometry and nutrient management in Pigeon pea (Cajanus cajan) + groundnut (Arachis hypogaea) intercropping system. Indian Journal of Agronomy 41 (2): 329-31.

Tripathi, N.C. and Chauhan, S.P.S. 1990. Response of Pigeon pea (Cajanus cajan) varieties to varying plant populations. Indian Journal of Agronomy 35 (3): 322-23.

\section{How to cite this article:}

Aditya Kumar Singh. 2018. Evaluate the Performance of Pigeon pea (Cajanus cajan) as Influenced by Varieties and Plant Geometry in Rain fed Condition Int.J.Curr.Microbiol.App.Sci. 7(07): 2351-2355. doi: https://doi.org/10.20546/ijcmas.2018.707.273 